\title{
First report of Pseudomonas syringae pv. actinidiae causing kiwifruit bacterial canker in New Zealand
}

\author{
Kerry R. Everett • Robert K. Taylor • Megan K. Romberg • Jonathan Rees-George • \\ Robert A. Fullerton - Joel L. Vanneste - Mike A. Manning
}

Received: 15 July 2011 /Accepted: 12 August 2011 /Published online: 29 September 2011

(C) Australasian Plant Pathology Society Inc. 2011

\begin{abstract}
Leaves from gold kiwifruit plants, Actinidia chinensis, with dark brown angular spots and flowers that were brown and wilted, first yielded non-fluorescent bacterial colonies following isolation. These bacterial colonies were identified by diagnostic polymerase chain reaction (PCR) as Pseudomonas syringae pv. actinidiae. These samples were obtained from the Te Puke region of New Zealand. All isolates were Gram negative and were levan positive, oxidase negative, potato soft rot negative, arginine dehydrolase negative and tobacco hypersensitivity positive (LOPAT 1a). Sequences of the $g y r B$ and the $r p o D$ genes of these isolates were $100 \%$ homologous to sequences of P.s. pv. actinidiae deposited in GenBank including the type strain. Koch's postulates were proven by pathogenicity tests on kiwifruit seedlings.
\end{abstract}

K. R. Everett $(\triangle) \cdot J$. Rees-George $\cdot$ R. A. Fullerton

M. A. Manning

The New Zealand Institute for Plant \& Food Research Limited,

Mt Albert Research Centre,

120 Mt Albert Road,

Auckland 1025, New Zealand

e-mail: Kerry.Everett@plantandfood.co.nz

J. L. Vanneste

Ruakura Research Centre,

East Street,

Hamilton 3214, New Zealand

R. K. Taylor $\cdot$ M. K. Romberg

Plant Health \& Environment Laboratory, Investigation \&

Diagnostic Centres, Ministry of Agriculture and Forestry,

231 Morrin Road, St Johns,

Auckland 1072, New Zealand
Keywords Actinidia chinensis · Pseudomonas syringae pv. actinidiae . Fluorescence $\cdot$ Te Puke $\cdot$ New Zealand

Kiwifruit (Actinidia spp.) is an economically important fruit crop grown in New Zealand, Italy, France, Chile and many other countries. In New Zealand, kiwifruit earns c. \$NZ1 billion per annum, and is the second most important horticultural export crop by value. Kiwifruit originates in Asia, and since the commercialisation of Actinidia deliciosa 'Hayward' by New Zealand growers and government agencies in the $1980 \mathrm{~s}$, a breeding programme based on the importation of germplasm from Asia has been established in New Zealand (Ferguson and Huang 2007). In the early 1990 s, the first economically significant product of the government and industry-sponsored breeding programme was commercialised (Actinidia chinensis 'Hort16A') and this variety is now grown throughout the world. A further species of kiwifruit (A. arguta) has also been commercialised (Warrington and Weston 1990) by New Zealand breeders, and is now marketed as Kiwiberry.

Pseudomonas syringae pv. actinidiae (Psa) was first described causing a disease of kiwifruit (Actinidia deliciosa) in Japan in 1989 (Takikawa et al. 1989). Since then it has been reported from Korea (Koh and Lee 1992), Italy (Scortichini 1994), Portugal (Balestra et al. 2010), China (CABI and EPPO 2008), France (Vanneste et al. 2011a; EPPO 2010), and Chile (Anonymous 2011). This pathogen can cause serious symptoms of cane die-back and vine death, and less serious symptoms of leaf spotting and flower wilting, accompanied by flower and bud drop (Serizawa et al. 1989). Psa is pathogenic on all commercial 
Fig. 1 Symptoms in the field showing a dark angular leaf spots, $\mathbf{b}$ wilted and browned Actinidia chinensis 'Hort16A' flowers and cane dieback, wilting and browning in early November 2010
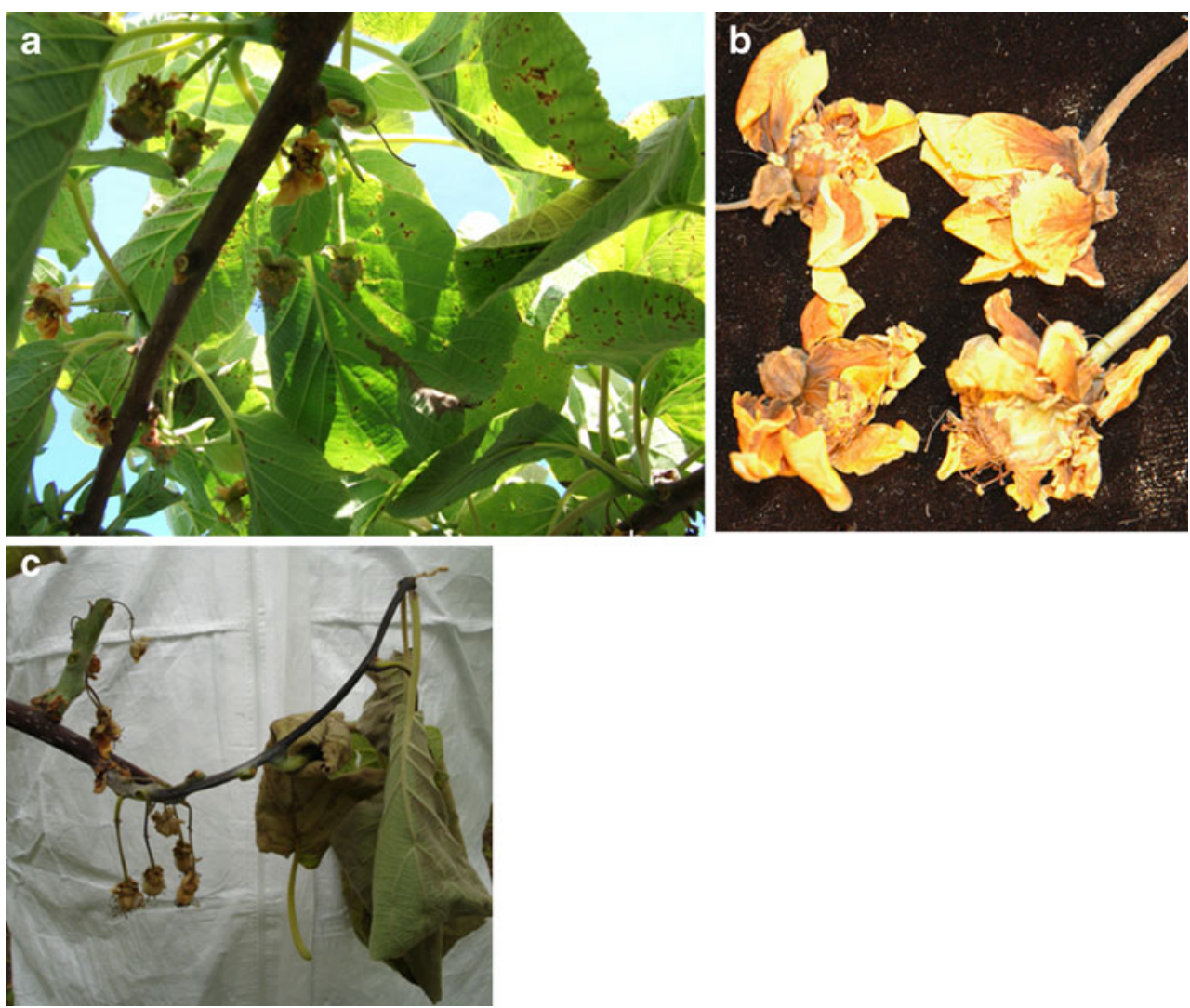

species of kiwifruit: A. deliciosa 'Hayward', A. chinensis 'Hort16A' (Ferrante and Scortichini 2009) and A. arguta (Serizawa et al. 1989). Symptoms resembling those caused by Psa were first observed on Actinidia chinensis in $\mathrm{Te}$ Puke, Bay of Plenty, New Zealand in the first week of November 2010. The symptoms consisted of angular necrotic dark brown leaf spots and wilting and browning of flowers, and a number of shoots showing blackening and terminal wilting and die-back. (Fig. 1). In early December
2010, similar symptoms were observed on flowers and leaves of 'Hayward' (Fig. 2). After a further 3 months, production of red ooze was observed from affected canes and trunks of Actinidia chinensis as well as the formation of young cankers at the bases of canes (Fig. 3). White-creamy bacterial colonies that did not fluoresce on King's medium B (King et al. 1954) were consistently isolated from both leaf spots and affected flower petals from 'Hort16A' sampled in November 2010.
Fig. 2 Leaf spots (a) and brown and wilted Actinidia deliciosa 'Hayward' flowers (b) in the field in early December 2010
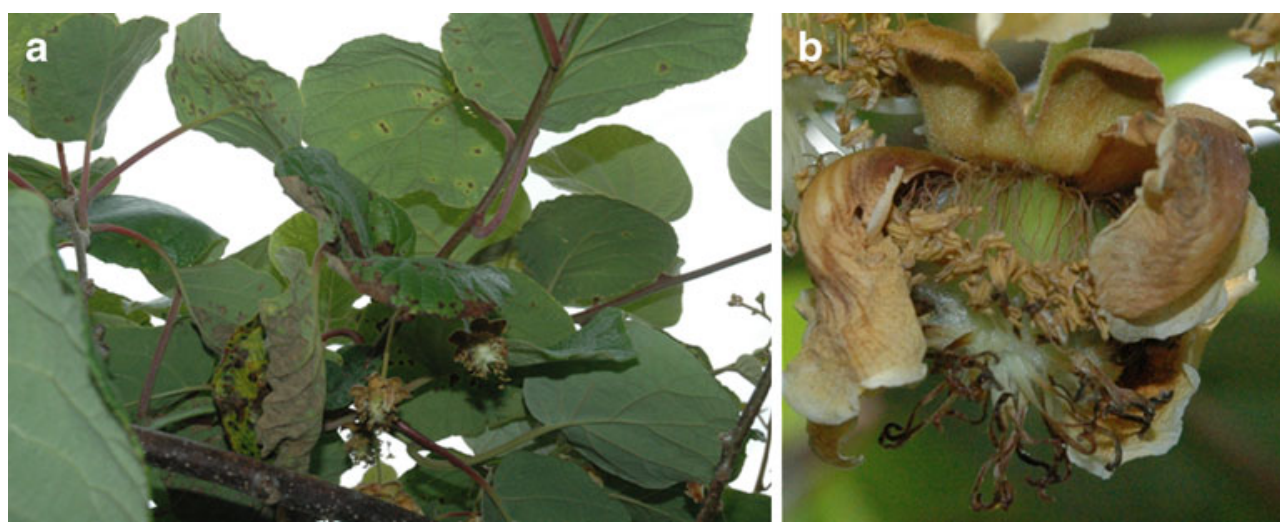

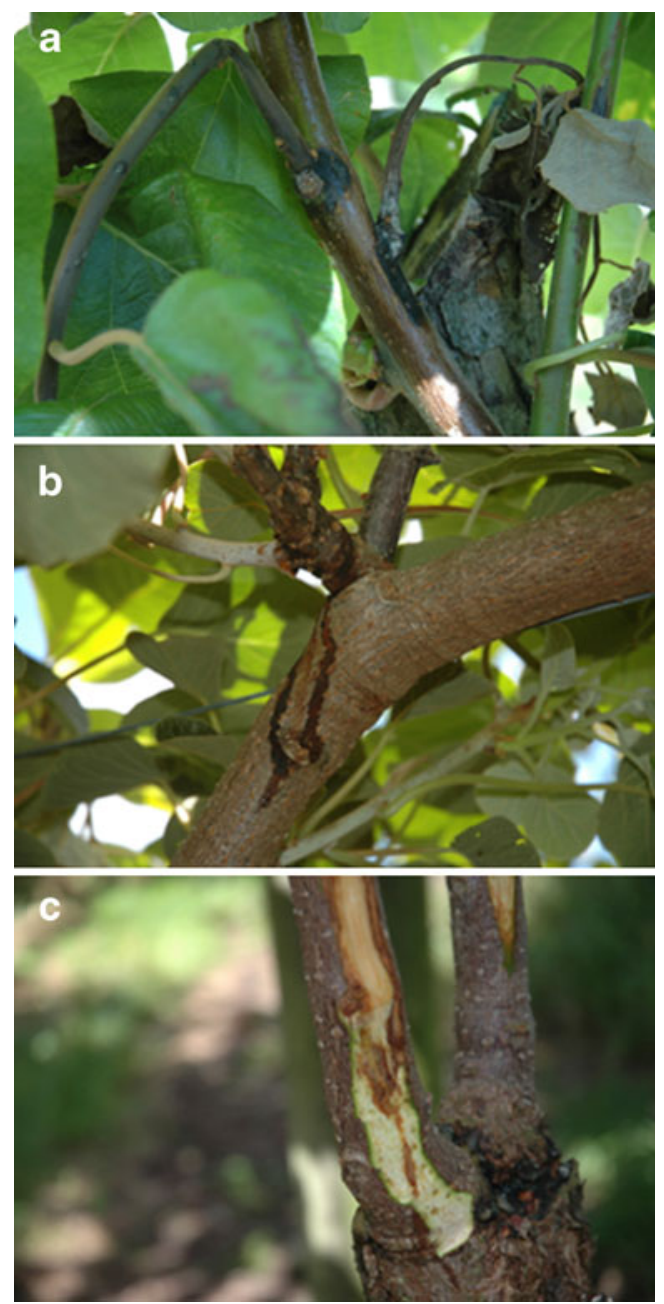

Fig. 3 Young canker forming at the base of canes (a), red exudate from young canker (b) and brown staining of vascular tissue (c) on Actinidia chinensis 'Hort16A' in February 2011 in the field in Te Puke, New Zealand

All isolates were Gram negative and showed characteristics of Pseudomonas syringae LOPAT group 1a, i.e., levan positive, oxidase negative, potato soft rot negative, arginine dehydrolase negative and tobacco hypersensitivity positive (Lelliott et al. 1966). Testing of DNA extracted from cultures from leaf spots and flowers with the specific PCR primers Psa F1/R2 and Psa F3/R4 (Rees-George et al. 2010) confirmed that these isolates were Psa (Fig. 4). DNA extracted from these cultures was also amplified by the Psa specific primers PAV1/P22 (Scortichini et al. 2002).

The housekeeping genes gyrB and $r p o D$ (Sarkar and Guttman 2004) were amplified from two New Zealand isolates (ICMP 18708 and 18801), producing a $600 \mathrm{bp}$ amplicon for each gene. BLAST analysis of these amplicons showed that the regions were $100 \%$ homologous to the respective Psa sequences in GenBank, accessions FN652889 and FN652897 from the 2008 epidemic in Italy (Ferrante and Scortichini 2010) for the gyrB gene, and FN433222 and AB016304 from the type strain (Kw-11, ICMP 9617) for the rpoD gene. Analysis of neighbour joining trees generated in Geneious Pro (ver. 5.0.4) placed these isolates into Group 1, as defined by Sarkar and Guttman (2004), which also contains the Psa type strain from Japan (ICMP 9617 or Kw-11).

Pathogenicity tests with three selected isolates of Psa from New Zealand (ICMP 18708, 18801 and 18805) were conducted on kiwifruit (A. chinensis 'Hort16A') seedlings. A bacterial suspension (c. $10^{8} \mathrm{cfu} / \mathrm{mL}$ ) from each isolate was sprayed onto the abaxial sides of the leaves of five seedlings without wounding. After inoculation, the seedlings were kept in a humid saturated environment at c. $20^{\circ} \mathrm{C}$ under ambient light and checked daily for symptoms. Controls were inoculated in the same way using sterile bacteriological saline $(0.85 \% \mathrm{NaCl})$. The pathogenicity tests were performed twice. Necrotic leaf spots developed on the kiwifruit leaves 7 days after inoculation. These symptoms were similar to those caused by natural infections. Bacterial colonies isolated from the

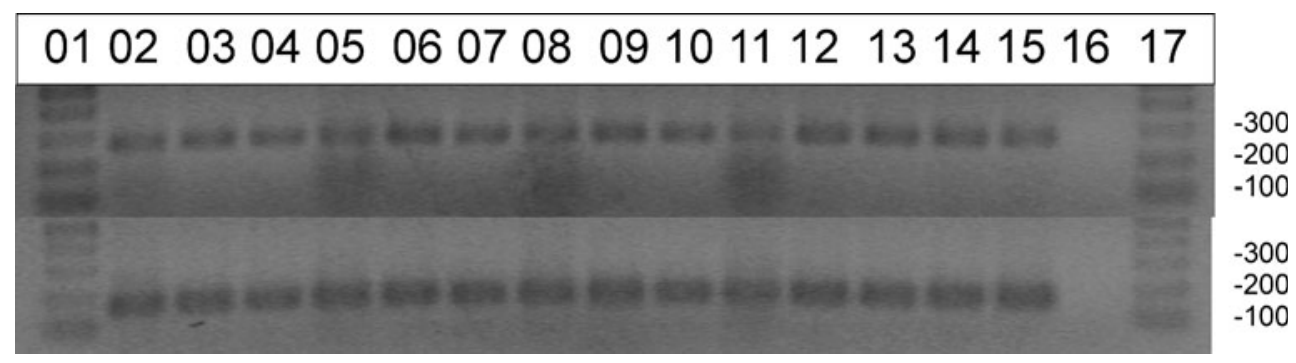

Fig. 4 PCR reactions using primers PsaF1/R2 (top) and PsaF3/R4 (bottom) to identify Pseudomonas syringae pv. actinidiae. Bacterial DNA was extracted from; flowers 2, 3, 4, 5, 6, 7, and leaves 8, 9, 10,
11, 12, 13. 14. P.s. pv. actinidiae ICMP 9617, 15. ICMP 9855. Lanes 1 , and $17=1 \mathrm{~Kb}$ Plus DNA marker (Invitrogen), Lane 16 is the water control 
Fig. 5 Pseudomonas species grown at $25^{\circ} \mathrm{C}$ on King's medium $\mathrm{B}$ and examined under UV. Some cultures were stored at $4^{\circ} \mathrm{C}$ for 2 weeks before photographing. Isolates grown on Kings' medium B in Petri plates were Pseudomonas syringae pv. actinidiae type strain from Japan (a; ICMP 9617), strains KACC 10754,10594 and 10584 from Korea $(b, c$ and $e)$, strain B4 $(d)$ and strain $\mathrm{BF}(f)$ from two properties in the Bay of Plenty, New Zealand

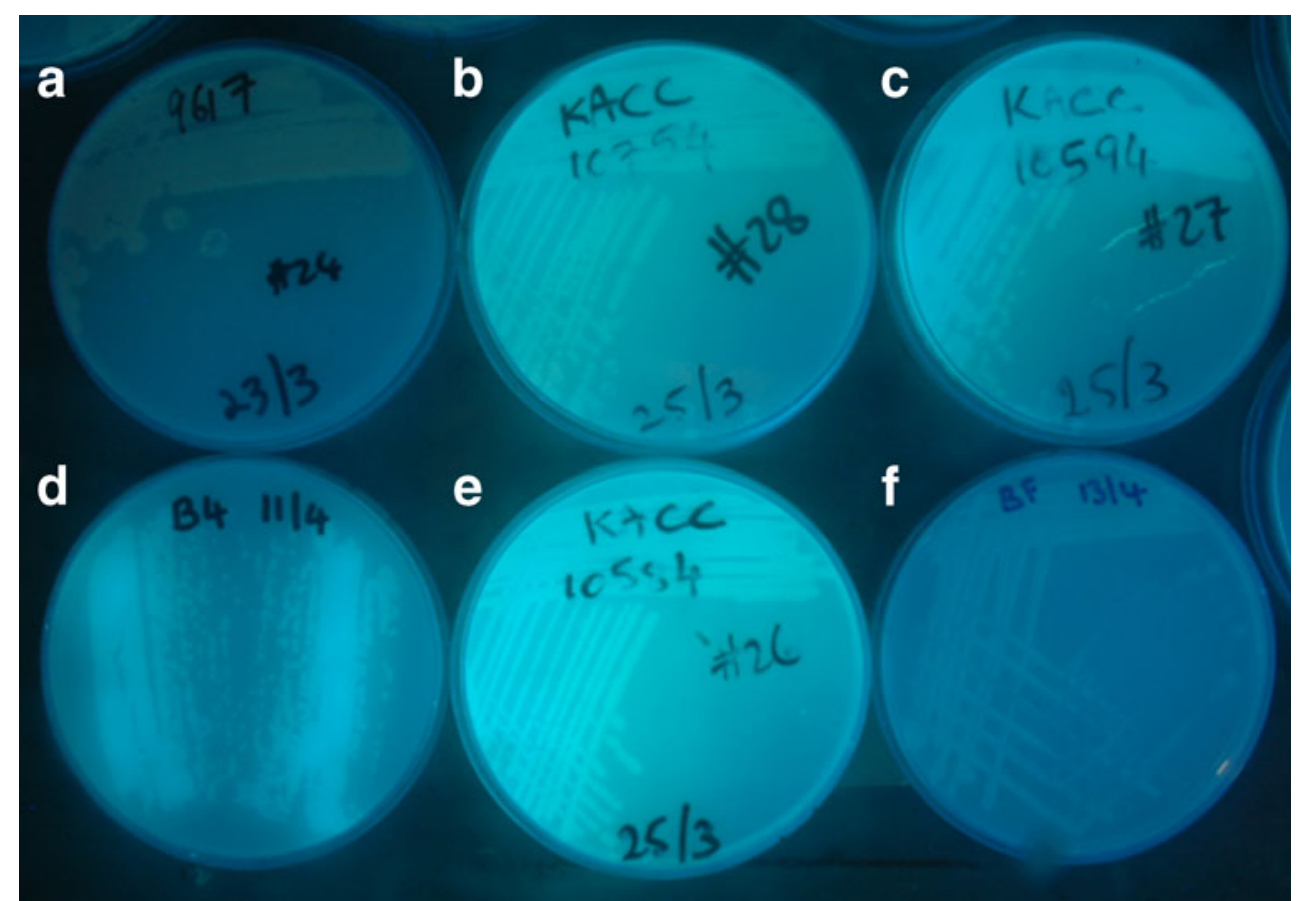

leaf spots were identified as Psa by PCR tests using specific primers PsaR1/R2, fulfilling Koch's postulates. No disease symptoms developed on the control plants. Later isolations, from A. chinensis in January 2011 were of both fluorescent and non-fluorescent colonies (Fig. 5). The identity of these two isolates (B4 and BF) was confirmed using the primers of Rees-George et al. (2010) in both conventional and real-time PCR reactions. The product was $100 \%$ homologous to the type strain (ICMP 9617 or Kw-11) from Japan following sequencing and a BLAST search in GenBank. Fluorescence has been shown to be a variable quality in the pseudomonads (Palleroni 1984), and recently faint fluorescence has been reported for some strains of Psa from Italy and France (Vanneste et al. 2011a, Vanneste et al. 2011b). The fluorescence reported here is not faint (Fig. 5). The identity of the Korean isolates (KACC 10754, 10594 and 10584) has previously been confirmed as Psa (Rees-George et al. 2010).

Recently, Psa was recorded to cause disease symptoms on 'Hort16A' for the first time, in Italy (Ferrante and Scortichini 2009). The epidemic affecting 'Hort16A' in Italy was caused by a strain that appeared to be more virulent than a strain reported in 1994 (Scortichini 1994; Balestra et al. 2009; Ferrante and Scortichini 2010). The epidemic in Italy has caused severe vine losses, with removal of entire orchards as a consequence (Balestra et al. 2009). It is estimated that economic losses of 2 million Euros will result from the epidemic in Italy. If the strain in New Zealand is confirmed to be the same as that causing this recent outbreak in Italy, then, depending on climatic differences, economic losses can also be expected.

Acknowledgements The Foundation for Research Science and Technology (contract CO2X0501 Better Border Biosecurity) for part-funding KRE and JRG, and contract CO6X0810 Low Impact Disease Control for funding MAM and RAF. Zespri International and The New Zealand Institute for Plant \& Food Research Limited (KRIP project 09-01) for funding JLV. MAF core funding for RKT and MKR.

\section{References}

Anonymous (2011) Bacterial canker, kiwifruit- Chile: First report (O’Higgins, Maule). http://www.promedmail.org/pls/apex/f? p=2400:1001:::NO::F2400_P1001_BACK_PAGE, F2400_P1001_PUB_MAIL_ID:1000,87723. Accessed 5 July 2011

Balestra GM, Mazzaglia A, Quattrucci A, Renzi M, Rossetti A (2009) Current status of bacterial canker spread on kiwifruit in Italy. Australas Plant Dis Notes 4:34-36

Balestra GM, Renzi M, Mazzaglia A (2010) First report on bacterial canker of Actinidia deliciosa caused by Pseudomonas syringae pv. actinidiae in Portugal. New Disease Reports 22:10 
CABI, EPPO (2008) Pseudomonas syringae pv. actinidiae. [Distribution map]. Distribution maps of plant diseases, October (edition 1) map 1043. CABI, Wallingford

EPPO (2010) First record of Pseudomonas syringae pv. actinidiae in France. EPPO Reporting Service 10:188

Ferguson AR, Huang H (2007) Genetic resources of kiwifruit: domestication and breeding. In: Janick J (ed) Horticultural reviews, vol 33. Wiley, Hoboken. doi:10.1002/9780470168011. ch1

Ferrante P, Scortichini M (2009) Identification of Pseudomonas syringae pv. actinidiae as causal agent of bacterial canker of yellow kiwifruit (Actinidia chinensis Planchon) in Central Italy. J Phytopathol 157 (11/12):768-770. doi:10.1111/j.1439-0434.2009.01550.x

Ferrante P, Scortichini M (2010) Molecular and phenotypic features of Pseudomonas syringae pv. actinidiae isolated during recent epidemics of bacterial canker on yellow kiwifruit (Actinidia chinensis) in central Italy. Plant Pathol 59(5):954-962

King EO, Ward MK, Raney DE (1954) Two simple media for the demonstration of pyocyanin and fluorescin. J Lab Clin Med 44:301-307

Koh Y, Lee D (1992) Canker of kiwifruit by Pseudomonas syringae pv. morsprunorum. Kor J Plant Pathol 8:119-122

Lelliott RA, Billing E, Hayward AC (1966) A determinative scheme for the fluorescent plant pathogenic pseudomonads. J Appl Bacteriol 29:470-489

Palleroni NJ (1984) Family I. Pseudomonadaceae. In: Krieg NR, Holt JG (eds) Bergey's manual of determinative bacteriology. William \& Wilkins Co., Baltimore, pp 141-199

Rees-George J, Vanneste JL, Cornish DA, Pushparajah IPS, Yu J, Templeton MD, Everett KR (2010) Detection of Pseudomonas syringae pv. actinidiae using Polymerase Chain Reaction (PCR) primers based on the $16 \mathrm{~S}-23 \mathrm{~S}$ rDNA intertranscribed spacer region and comparison with PCR primers based on other gene regions. Plant Pathol 59:453-464. doi:10.1111/j.13653059.2010.02259.x

Sarkar SF, Guttman DS (2004) Evolution of the core genome of Pseudomonas syringae, a highly clonal, endemic plant pathogen. Appl Environ Microbiol 70(4):1999-2012. doi:10.1128/ AEM.70.4.1999-2012.2004

Scortichini M (1994) Occurrence of Pseudomonas syringae pv. actinidiae on kiwifruit in Italy. Plant Pathol 43(6):1035-1038

Scortichini M, Marchesi U, Di Prospero P (2002) Genetic relatedness among Pseudomonas avellanae, P. syringae pv. theae and P.s. pv. actinidiae, and their identification. Eur J Plant Pathol 108 (3):269-278. doi:10.1023/A:1015178104513

Serizawa S, Ichikawa T, Takikawa Y, Tsuyumu S, Goto M (1989) Occurrence of bacterial canker of kiwifruit in Japan: description of symptoms, isolation of the pathogen and screening of bactericides. Ann Phytopathol Soc Jpn 55 (4):427-436

Takikawa Y, Serizawa S, Ichikawa T, Tsuyumu S, Goto M (1989) Pseudomonas syringae pv. actinidiae pv. nov.: the causal bacterium of canker of kiwifruit in Japan. Ann Phytopathol Soc Jpn 55(4):437-444

Vanneste J, Poliakoff F, Audusseau C, Cornish D, Paillard S, Rivoal C, Yu J (2011a) First report of Pseudomonas syringae pv. actinidiae the causal agent of bacterial canker of kiwifruit on Actinidia deliciosa in France. Plant Dis 95(10):1311

Vanneste JL, Cornish DA, Yu J, Audusseau C, Paillard S, Rivoal C, Poliakoff F (2011b) Presence of the effector gene hopA1 in strains of Pseudomonas syringae pv. actinidiae isolated from France and Italy. New Zealand Plant Protection 64:252258

Warrington IJ, Weston GC (eds) (1990) Kiwifruit: science and management. Ray Richards Publisher and NZ Society for Horticultural Science Inc., Auckland 